\title{
The Workplace Comedy and Pandemic Politics in Greg Daniels' Upload
}

\author{
Sean Brayton \\ Correspondence: Sean Brayton, Associate Professor, University of Lethbridge, Department of Kinesiology and Physical \\ Education, Canada.
}

Received: January 12, 2021

Accepted: February 12, 2021

Online Published: February 21, 2021

doi:10.11114/smc.v9i1.5128

URL: https://doi.org/10.11114/smc.v9i1.5128

\begin{abstract}
This paper examines the critical potential and pedagogic possibilities of the workplace television comedy during the COVID-19 pandemic. It is particularly interested in Greg Daniels' Upload, a series that debuted during the first wave of infections in North America. Although it was produced before the current health crisis, Upload offers a prescient social commentary on the depravities of late capitalism, one that speaks to present concerns over access to vital health resources and the importance of "essential" workers, specifically in the service industry. However, Upload is driven by a liberal version of multiculturalism that emphasizes racial equality and ostensibly recognizes "difference" but downplays economic disparities and racial divisions of labor even as it draws on them repeatedly in its critique of inequality. Whereas the series effectively challenges the monetization of everyday life and death, a point of praise for many critics, it fails to disrupt or even call attention to how low-wage and purportedly low-skilled work is currently and historically racialized in the US. As a result, Upload's efficacy as a social commentary and indictment of late capitalism is more interested in the unequal distribution of essential resources and services than the political economy of their provision, that is, the social relations of their production.
\end{abstract}

Keywords: television, workplace comedy, labor, pandemic, upload

\section{Introduction}

With unprecedented scale and clarity, the COVID-19 crisis has magnified some of the most egregious depravities of late capitalism, including severe shortages of medical supplies, affordable housing, health care, rent control and a living wage. Although such problems precede the pandemic, they are now glaringly obvious after waves of infections, near-global lockdowns and mandatory quarantines. In the US, for instance, the prohibitive cost of a health care system driven by profit has not only denied diagnosis and treatment of the working poor and marginalized communities; it has also prevented wide sectors of a population with symptoms of the respiratory disease from seeking tests and results (Bragman, 2020). As the US economy deals with more than 40 million layoffs, people "fortunate" enough to work remotely have found the disturbing conversion of their homes and apartments into an inescapable workplace that exemplifies what Jonathan Crary (2013) would call "terminal capitalism." In addition, the provision of the most basic amenities is entirely reliant on jobs performed disproportionately by people of color and migrants as an underpaid, overworked and often unprotected army of supply-chain workers and cleaners that enable the normal functioning of everyday life (Al-Gharbi, 2020). While there are myriad economic and moral lessons to learn from the disaster, the COVID-19 crisis has drawn sharp attention to the unequal access to health care and the problematic politics of production and consumption at a moment also defined by government incompetence and "race rebellions" in the US and abroad triggered by the police killings of Breonna Taylor and George Floyd. As such, the racialized dimensions of economic disparity and morbidity rates in the US, for instance, are overwhelmingly apparent during the ongoing calamity when late capitalism and neoliberalism have (again) proved colossal failures for anyone other than the ultra-affluent and predominately white.

If the global economy seemed to plummet during the pandemic, so did production in the culture industries. While those under quarantine healthy and relatively privileged enough to casually unwind binged on various online streaming platforms and added to soaring media revenues, the creation of new film and television content was mostly suspended or cancelled during the early months of the crisis. From the deferred releases of blockbuster films like No Time to Die, The Batman, Mulan and Candyman to the halted production of television and streaming series like The Voice, G.L.O.W., The Handmaid's Tale and The Good Fight, new material in the culture industries was abruptly curtailed by COVID-19 complications, which now apparently include additional expenses of $\$ 500,000$ per television episode for studio 
ventilation upgrades, increased insurance premiums, and personal protective equipment (Sepinwall, 2020b). Although some serials produced before COVID-19 eerily foreshadowed the current health disaster-like Season Three of Netflix's Alta Mar (2020) in which a viral outbreak threatens the passengers of a luxury ocean liner, and Amazon's Utopia (2020) where a global flu pandemic is nigh-original fictional programming made during lockdown was relatively rare. Such sweeping paucity led some critics to speculate about not only the solvency of cinemas but also a potential dearth of nominees for awards season. As a result, critics can only hypothesize how Hollywood will survive the crisis and, moreover, how popular culture might respond to the social, economic and political fallout of the crisis (Buchanan, 2020).

This may be particularly true of the "workplace comedy", a popular television genre that is difficult to imagine after widespread layoffs and the displacement of office culture into work-from-home conditions. Indeed, some of the more enduring sitcoms like The Office (2005-2013), Parks and Recreation (2009-2020), 30 Rock (2006-2013) and Veep (2012-2019), for instance, rely on the physical workplace and "water cooler" exchanges for narrative direction and punchlines. Of particular interest here is the American showrunner Greg Daniels, whose work includes the US adaptation of The Office, Parks and Recreation, and, most recently, Space Force (2020) and Upload (2020), both of which debuted in May during the first outbreak. At a glance, it seems that Daniels (next to King of the Hill colleague Mike Judge) is a veritable maestro of workplace satire in US television, earning 10 Emmy awards and 41 nominations as well as great anticipation for his latest Netflix fare (especially Space Force, starring Steve Carell). As a workplace comedy hybrid, Upload offers a pastiche plot comprised of a bespoke afterlife similar to The Good Place (2016-2020) accessed when a decedent's consciousness is uploaded to a platform monitored by a customer service agent not unlike the telemarketers of Sorry to Bother You (2018). The series offers a sardonic, science-fictional glimpse of a future when eternal life is not only possible through virtual reality but also mediated along the same socioeconomic lines of late capitalism today. Much like daily life in the pandemic, white bourgeois comfort in and out of the afterlife in Upload is enabled only by black and brown characters as "essential" workers, making the series difficult to watch without contemplating the socioeconomic disparities and racial divisions of labor illuminated by the current disaster.

To appreciate how Upload provides an unwitting but prescient commentary on the COVID-19 crisis, I begin with an overview of the workplace comedy, underscoring the genre's cultural and historical importance and popularity in US television. I then bring into focus some of the defining features of the COVID-19 disaster apropos late capitalism as a way of unpacking and appreciating the nuances of Daniels' latest workplace comedy. Although Upload was produced before the outbreak and was met with mostly mediocre reviews, its release during the first wave of infections in the US portends key issues that define the calamity, including access to amenities and health care as well as the impact of essential workers during a health crisis. Though the series presents a twist to the workplace comedy in an era of "physical distancing" by forecasting a budding romance between a client and call center operator, it is also limited by its inability to imagine the perils of capitalism beyond the politics of consumption. In other words, the problems of neoliberalism in Upload are rooted in access rather than exploitation, an approach that fails to adequately interrogate existing power relations in the world of work as well as the racial divisions of labor the series ostensibly aims to lampoon.

\section{The Workplace Comedy as Social Commentary}

Though it was described in 2016 as suffering a "slow and painful death" on major networks, the workplace comedy has a long history in US television, one that extends from The Mary Tyler Moore Show (1970-1977), Alice (1976-1985), WKRP in Cincinnati (1978-1982) and Murphy Brown (1988-1998) to NewsRadio (1995-1999), 30 Rock, Better Off Ted (2009-2010) and Veep, for instance (Hunt, 2016, par. 1). The genre is a reliable staple of US network television that spans a wide range of stations and eras and often engages with the cultural politics of its time. This is particularly true of The Mary Tyler Moore Show which, as Bonnie Dow argues, "marked a qualitative shift in public consciousness of the presence of an organized feminist movement" and "disrupted hegemonic practices of female representation" by rejecting "the 'good wife' character type" in popular sitcoms (1996, pp. xvi, 34). The acclaimed workplace comedy and its various descendants, including Murphy Brown, Suddenly Susan (1996-2000) and Ally McBeal (1997-2002), offered both complementary and competing versions of (post)feminist politics wherein careerism seemed to promise women social and economic autonomy but not always without consequences. As Rachel Dubrofsky argues, Ally McBeal presented its eponymous character as "the embodiment of the internalization of fundamental Feminist goals that become personalized, aestheticized, and thus, depoliticized" (2002, p. 279). Throughout the series "empowerment, equality, and femininity" were enabled in and by the workplace but in ways that obviated "the structural power dynamics that shape and constrain diverse women's experiences and choices" (Ouellette, 2002, p. 320).

Of course, the workplace is not always portrayed as a gateway to success and self-fulfillment. The malaise of post-industrial labor, for instance, is typified by Ricky Gervais and Stephen Merchant's The Office (2001-2003), the renowned British mockumentary set in the Slough office of the fictional Wernham Hogg paper company. Though it 
aired for only two seasons, the series was adroit at satirizing the lingering misogyny of the "post-feminist" workplace, corporate ambition, and careerism in an increasingly irrelevant industry (i.e., analog stationary in a digital world). As Tara Brabazon explains, The Office "translated the boredom, banality and pettiness of office life into comedy" whilst underscoring the disconnect between "new corporate capitalism" and "the language of team-building and flexible employment" (2005, pp. 103, 109). The cult classic was adapted for NBC and US audiences in 2005 by Greg Daniels and aired for nine seasons much to the delight of critics and viewers. Set in Scranton, Pennsylvania, at Dunder Mifflin paper company, the US version of The Office presented comedic scenarios typical of post-Fordist working conditions - from the corporate surveillance of email communications and employee drug testing to requisite diversity training, mergers and human resource interventions - all of which was served with heavy dollops of sarcasm and silliness directed most often at regional manager Michael Scott and his assistant/salesman Dwight Schrute. In other words, the series was notorious for taunting the language and practices of corporate management used to soften the fallout of downsizing and flexible accumulation often by mocking the importance of gainful employment entirely.

A similar depiction of office work appeared in Daniels' equally vaunted television series, Parks and Recreation, which aired for seven seasons on NBC. Set in the fictional town of Pawnee, Indiana, the series was, in many ways, the public sector companion to the mockery of the corporate world found in The Office, drawing a caricature of the absurdities, inefficiencies and general claptrap of municipal bureaucracies and local government. Although Parks and Recreation is often described as a "political satire", its approach to office work was somewhat ambivalent. Mid-level bureaucrats like Leslie Knope and Ben Wyatt were genuine careerists with endearing personality quirks, but other characters practiced amusing indifference if not disdain towards their jobs in public administration. Such animosity was personified by Parks Director Ron Swanson, whose abhorrence for "big government" was equalled only by his love for woodworking and whiskey. Incidentally, self-actualization for most characters was found anywhere but the workplace, which was offset by side hustles and hobbies that offered a trove of comic material. As in The Office, the workplace in Parks and Recreation was portrayed more as a venue for pranks and buffoonery than a site of productivity and professional achievement much less labor activism.

If network television typically depicts the modern workplace as brimming with hijinks, it also occasionally reveals nuanced class politics, as in Justin Spitzer's Superstore (2015-2020). In this multiracial satire of Walmart culture, wage labor is a reluctant reality for the central characters-some of whom describe it as "dead end" and "soul crushing"-but also a site of social, political, and economic struggle. Superstore indexes the absurdities of retail work in a fictional Missouri department store called Cloud Nine, playing with manager-employee tension found in other workplace comedies. It often does so, however, on a collective rather than individual level that surpasses simple pranks. In Season One, for instance, workers use a wildcat strike to force a district manager to rehire Glenn, who is reprimanded for finagling a paid maternity leave for an employee; in Season Two, Cloud Nine's staff challenges management's decision to downsize the workforce; in Season Three, the employees try to subsidize their own health care plan, which is ironically mistaken for a pyramid scheme; later in the season, the employees band together to thwart a daily sales quota required for a store "upgrade" that promises only longer hours and poor working conditions; and in Season Five the workers actually unionize to ward off automation and redundancies. Evidently, labor struggles in the series are broadly conceived, often comical but always integral to the post-industrial workplace, a theme that distinguishes Superstore from other office satires.

Whereas Superstore is more fluent in labor politics, exploitation and organization than The Office and Parks and Recreation, for instance, they are all comically attuned to what David Graeber called "bullshit jobs": positions in administration, sales, public relations, human resources and corporate law, for instance, that fail to produce any social value and merely exist to "identify with the perspectives and sensibilities of the ruling class-and particularly its financial avatars" (2018, p. xxi). To this end, Daniels' work is particularly important as a critique of the widespread futility of post-industrial labor, at least until the debut of Upload. The customer service work deemed trivial in The Office and Parks and Recreation becomes essential labor in Upload, which articulates rather neatly with the public perception of working conditions during the COVID-19 pandemic. As I argue below, Upload provides important and prescient social commentaries on critical issues highlighted during the ongoing health crisis, most notably access to health care and amenities and the importance of essential labor, both of which distinguish the series from Daniels' previous office satires. If the workplace comedy is a barometer for gauging the trends and transformations of wage labor under late capitalism, as critics and commentators have often insisted, it may assume heightened significance during periods of economic crisis and workers' struggles, particularly during a health disaster when resources and services are in high demand but short supply.

\section{Method}

To understand the significance and the limitations of Upload as a social commentary within and beyond the genre of workplace television comedies, I use a textual analysis of the first season of the series consisting of 10 episodes. 
Although studies of audience reception, production and political economy are all important aspects of media analysis, the strength of a textual analysis is the detailed degree to which it can explain and unpack how images, dialogue, settings, and general narrative features of a text (film, television series, novel, music video, advertisement, etc.) are able to articulate and gain cultural purchase with wider meanings and messages in the political and economic milieux of a particular historical moment. As Norman Fairclough explains, "Texts are not just effects of linguistic structures and orders of discourse, they are also effects of other social structures, and of social practices" that determine the "selection of certain structural possibilities and the exclusion of others" (2003, p. 25). To this end, a textual analysis is concerned not with unearthing "hidden meanings" of a film or television series, for instance, but rather exploring, explaining and interrogating how the representations and narrative vernacular employed by a text become intelligible only within a certain historical and cultural setting, one that is now informed by pandemic politics, struggles for access to health care, and essential labor under late capitalism that all appear in various ways throughout Upload. In other words, a textual analysis questions "how the culture industries produce specific artefacts that reproduce the social discourses which are embedded in the key conflicts and struggles of the day" (Kellner, 1995, pp. 3-4). As such, the meanings of Upload are not intrinsic to the text but rather emerge in a cultural and intertextual conversation with other workplace television comedies and political, economic and even epidemiological events of great importance (Fairclough, 1995). In other words, a textual analysis can help us appreciate Upload as an insightful but limited socioeconomic critique and media resource that is germane to the current crises of late capitalism illuminated by the COVID-19 pandemic.

\section{COVID-19 and the Crisis of Late Capitalism: Lessons and Limitations of Upload}

Upload was produced before the outbreak, but its central themes resonate with the myriad problems of late capitalism amplified by the COVID-19 crisis. The premise of the series is that by 2033 life after death is entirely achievable through scientific technologies and a series of apps. After dying, a decedent's consciousness could be uploaded to a virtual afterlife of one's affordability, from bucolic resorts with country-club activities and five-star amenities to "Two Gig" ghettos with Dickensian accommodations and limited contact with living loved ones. In a sense, the series "proposes uploading as a new health care industry" (Francisco, 2020, par. 9). Thankfully for the central characters, Nora Antony works as a customer service agent at Horizen, spending her workdays fielding calls and guiding recently deceased clients uploaded to the opulent Lakeview afterlife program that she describes as "a little too Ralph Lauren." Upload pairs Nora with an intrepid computer engineer and entrepreneur, Nathan Brown, who died suspiciously in a self-driving automobile collision shortly after revealing plans to "socialize" access to afterlife programs. Through 10 episodes, the series follows the budding romance between Nora and Nathan and highlights problems with monetized life qua afterlife, scientific hubris, and working conditions at the call center where Nora is employed. It also builds toward a murder mystery in which the central couple must ferret out suspects that may have benefited from and ultimately planned Nathan's untimely death, which is presumably connected to his plan to increase access to afterlife apps by eliminating fees. Evidently, the series is an ambitious blend of workplace comedy, romance, murder mystery and social commentary.

Although a second season of the series is apparently forthcoming, Upload received mostly mixed reviews in popular press. On the one hand, the series was frequently panned as cliché, vapid, and derivative. IndieWire, for example, called Upload "glossy and fleeting" with "little bearing on whether or not the people who are living or dead really matter all that much" (Greene, 2020, par. 7). Variety derided the virtual world presented in the series as "rushed ... or simply gross" (D'Addario, 2020, par. 3). On the other hand, some critics praised the series' acuity in lampooning the commodification of everyday life (and death). Rolling Stone underscored Upload's "sharp points about income inequality" in which the "have-nots have less than ever" (Sepinwall, 2020a, par. 6). As the digital media website Inverse noted, "with its imagined world so tied to the economics of big tech, it doesn't take long for Upload to stand out from other ... workplace comedies" as a "damning illustration of capitalism invading something even as natural as death" (Francisco, 2020, par. 7). Further, The Guardian summarized how "paradise waits not for the pure of heart but for the plump of wallet" in a series that skewers "the final culmination of a cruel capitalist ethic: even the alleged great equalizer [i.e., death] favors the rich" (Bramesco, 2020, par. 2). Evidently, many of the reviews sensitive to Upload's critique of late capitalism ruminated on socioeconomic inequality and disproportionate access to amenities, both of which are intrinsic to our current mode of production.

Critics and commentators, however, were less effusive about the limitations of Upload's anti-capitalist sensibility, particularly its treatment of labor politics in the very industries designated "essential" during the ongoing health care crisis. The Atlantic, for example, praised Upload's indictment of "radical inequality, peskily perennial adbots, tiered social system, and glitchy digital assistants" but was reticent about working conditions for human labor in the series (Gilbert, 2020, par. 13). For critics at Vulture, the series may "play best as a nightmare" of corporate predation but no mention is made of Upload's preoccupation with a mode of consumption rather than production (VanArendonk, 2020, par. 9). As a review at $N B C$ News pointed out, in Upload "the wealthy make afterlife access a privilege, just like health 
care is still a privilege in America" (Berlatsky, 2020, par. 10). To tease out the contradictions of the series and how it prioritizes users rather than producers, it is imperative to index and explain some of the ways in which Upload foregrounds late capitalism as unable and unwilling to provide equally across populations. In Upload, this orbits around access to a comfortable afterlife.

\subsection{Access to the Afterlife as Health Care}

The relevance of Upload to the present health care catastrophe and the pitfalls of late capitalism can be found immediately in its mis-en-scène. A North American viewer may be struck by the frequency of scenes in which background characters are wearing surgical masks and face coverings throughout the series, particularly when Nora is using public transit. While the use of personal protective equipment beyond hospitals is now commonplace (though somehow controversial in various parts of North America and Europe), the regular presence of characters wearing face masks is obviously consistent with the current COVID-19 climate. So not only is public transit implicitly racialized in Upload by the presence of mostly black and brown passengers; it is also a space of heightened risk of infection and general contamination, especially for the working poor and the "precariat" like Nora.

From there Upload builds its central critique of inequality, particularly as it relates to access to amenities and the necessities of the virtual world. By 2033 the struggle for public health care has apparently shifted towards the democratization of the afterlife. Nevertheless, a Medicare for All ethos runs throughout the series in opposition to the monetization of life and death. In Episode Five, for instance, we learn that Nora had foregone law school and sought employment at Horizen to cover the prohibitive costs of her late mother's medical bills. In other words, the burden of private health care is the narrative lever of the series, the formative event that leads Nora to Horizen and Lakeview and ultimately to Nathan. In addition, Nathan's "Freeyond" app aims to expand access to a comfortable virtual afterlife and is guided by the tagline, "Everyone deserves to live forever", which resonates with claims made throughout the series by protesters like the "Luds" (as in Luddites). Gathered outside of Horizen headquarters and Nora's workplace in Episode Four, the Luds wave placards that read "Uploading is a human right" and "Free government uploads" while chanting, "Do not end the fight; upload is a human right." In many ways, then, the struggle for access to uploading and the afterlife is a stand-in for access to health care championed by Medicare for All campaigns, as some critics have noted (see Francisco, 2020; Berlatsky, 2020).

In Upload, however, access to an afterlife of comfort is costly and contingent on the accumulated wealth of a decedent or their loved ones, that is, policy holders that are described as "owning" the uploaded client. Such a message is compounded in Episode Three when Aleesha (Nora's co-worker) insists that "income shouldn't determine your afterlife." We also learn that Nora's "family benefits" for uploading are extended to her ailing father, much like health insurance, but only if she achieves an arbitrary level of performance at work. Here, as in US culture at large, work is "a core eligibility standard for public assistance" in a "private welfare state" and "the single most important marker of 'deservingness"” (Gordon \& Bruch, 2020, pars. 4, 5). As such, care in the virtual afterlife hinges on not only disposable income but also economic productivity, the prime source of "value" in late capitalism that is somewhat ridiculed in the series. As Lakeview resident David Choak (meant to be the late American businessman and professional ratfucker David Koch) exclaims, "I lived a life of purpose; now this [playing golf] is my reward." Of course, if a decedent cannot afford the luxurious Lakeview virtual resort, less appealing but more affordable alternatives exist. In Episode Four, Nora offers Nathan a preview of the Two Gig ghetto, which is later described as fit only for "single moms, the handicapped [sic] and the poorest of the poor" who are "broke enough to qualify." Nora explains that Horizen ultimately "wants people to pay for upgrades; it's called capitalism." If the assumption here is that health care is supplanted by a greater interest in afterlife care, Upload foreshadows overlapping practices of privatization to lampoon the absurdities of late capitalism wherein both life and death are reduced to a market logic. Nora summarizes the fate of this logic rather neatly in Episode Ten when she observes that "it takes luck to upload", much like the acquisition and accumulation of wealth and one's lot in life, "and I don't come from luck."

It is the series' sketch of disparate access to the afterlife that brings Upload into a rather intimate conversation with the political economy of health care in the US, the COVID-19 crisis, and what Achille Mbembe calls "necropolitics" (2003, p. 11). The lack of adequate and affordable uploading, for instance, is governed by "the capacity to define who matters and who does not, who is disposable and who is not" (Mbembe, 2003, p. 27). For characters in Upload the Two Gig ghetto resembles what Mbembe might describe as a "death-world" in which living conditions of bare minimal survival grant its inhabitants a status of "living dead" (2003, p. 40). Here death itself becomes a source of value, a development routinely lampooned in the series that marks "a new space of capital that profits in killing and death, not to produce commodities, but as the commodity itself-a necroeconomy" (Haskaj, 2018, p. 1149). Indeed, Upload is especially effective as an indictment of neoliberalism's striking encroachment and colonization of all areas of social life. As Fatmir Haskaj suggests, under such conditions we find a "biopolitical intensification of death in the service of market forces" (2018, p. 1150). While amenities at Lakeview and the Two Gig zone in Upload may present a parable of health care in 
the US that is obviously removed from the genocide, war, and climate disasters often requisite of necroeconomies, death is absorbed by the logic of accumulation in all cases. As such, a framework of necropolitics helps us understand more precisely how late capitalism works during a pandemic not only in relation to looming problems of vaccine hording by the Global North (especially the European Union) and "immuno-nationalism" but also how the commodification of death gains critical traction in Daniels' workplace satire.

Uneven access to health care, however, is both symptomatic and constitutive of unequal labor relations. Under the terms of necrocapitalism, James Tyner claims, "exploitation and oppression ... materialize as inequalities to the exposure and occurrence of death", a phenomenon sharply illustrated by the current health crisis (2019, p. x). On the one hand, contact with COVID-19 is particularly concentrated among "expendable" workers, from delivery drivers, meat and poultry processors, and janitors to restaurant servers, grocery clerks, and health care aides. On the other hand, the pandemic has exposed the gaping holes in an already "ragged" and "shameful" social safety net in the US in relation to "flexible" labor found in such industries (Colin \& Bruch, 2020, par. 1). The conundrum is that health care in the US is mostly tied to employment benefits, reducing "health" to economic productivity and leaving the millions of laid-off workers without access to affordable health care. As Walker Bragman remarks, "cost barriers to health care are making the crisis worse", with an estimated 27 million Americans without health insurance at the time of Upload's release (2020, par. 22). In response, public support for Medicare for All has broadened across the US during the pandemic, much like it has for front-line workers and essential labor (Bragman, 2020). During the pandemic, of course, "when our collective health rests on limiting social contact, most front-line service workers are unable to take advantage of either paid leave or stable health coverage", a gross malfeasance of late capitalism seemingly at odds with the designation of much wage labor as "essential" (Gordon \& Bruch, 2020, par. 5). The importance of such work in the service industry, for instance, is underscored throughout Upload in ways that are unforeseen in Daniels' other workplace comedies and merit closer attention.

\subsection{Essential Workers of the Future}

Even a cursory glance at the series would find that Upload routinely places racialized characters in positions of wage labor in the service industries and health care that became widely declared "essential work" during the pandemic. When Nathan is rushed to the emergency room, for instance, he is helped by a cadre of black and brown women as nurses and physicians. In other scenes we find Latino lab technicians and Asian-American workers at AT\&T. Perhaps most obviously, the workforce of the Horizen call center is both racialized and gendered and includes black and mixed-race characters like Aleesha, Nora and Ivan as well Baltic immigrant Batia, all of whom are under the watchful eye of Lucy, the white supervisor. Strangely, the personnel also include Nathan's therapist "Ernie", who appears as a Golden Retriever "therapy pet" in Lakeview but is voiced by a middle-aged black man at Horizen. This workforce resembles the much heralded but underpaid customer service agents and call center workers at Amazon, corporate banks and other agencies (see Burgess \& Connell, 2006). Although such minor characters in Upload are typically used for comic relief rather than an incisive critique of racial hierarchies and divisions of labor, the visibility of these characters in industries deemed indispensable during the pandemic is not without merit, especially as the series appeared during the first wave of infections.

While the pandemic revealed myriad depravities of late capitalism, it also compelled the professional-managerial class working from home to realize the importance of heretofore "disposable" service workers. In March 2020, striking workers at Amazon, Instacart and Whole Foods, for instance, drew nationwide attention to the unsafe working conditions of order processing and delivery during a health disaster as well as the indispensability of labor in the service economy. As Musa al-Gharbi in The Baffler pointed out, "the relative ease and comfort that many in the professional-managerial class are experiencing during the pandemic ... is actually the product of thousands of low-paid 'invisible' workers" that are "disproportionately people of color" and are "paying the costs and exposing themselves to considerable risk, on behalf of those who are better off" (2020, pars. 3, 2). In other words, key elements of a predominantly white bourgeois social order are sustained by the work of racialized people that are historically overlooked by the class that benefits most from their labor, a situation that is not entirely removed from the discourse of race and labor found in Upload.

From the outset, the importance of customer service agents at Horizen is illustrated by their "angel" moniker, an informal job title for Nora, Aleesha, Ivan and sometimes Batia. The term is noteworthy not simply as a reference to a celestial afterlife used to sell Lakeview but rather as a way of depoliticizing the labor and demands of its customer service agents, much like the use of "heroes" during the pandemic; "angels", of course, bring miracles but have no material needs or desires of their own, a truism of sorts that ultimately trivializes the Horizen workers but not their work. Incidentally, while angels are nothing less than essential in the series they are treated by management and other professional labor as easily disposable, "low-wage clowns" whose work is sometimes outsourced to Finland and Kenya. And yet Nora explains to Nathan how overworked she is with 47 other clients and under pressure "to keep pleasing 
people" or face the consequences of diminished customer ratings. Nathan replies that "emotional work is real work!" Inspired by his support, Nora embarks on a quest to restore Nathan's scattered memory and learn of the circumstances surrounding his suspicious death. Nora's work, in other words, is essential to not only the comfort of Lakeview's guests, including Nathan's self-development and realization of aptitudes, but also the storyline of Upload. However, her customer service is not always recognized as such by other characters in the series. It is otherwise "hidden" labor that must be made visible to the audience.

Such a revelation appeared in a series of television commercials commissioned by Amazon during the pandemic. As employees walked out of fulfillment centers in spring 2020, the "heroes" commercials sought to recognize the paramount role of supply-chain workers during the crisis and encourage shoppers to consider every Amazon purchase an act of public service (Hess, 2020). In "Thank you, Amazon heroes", for instance, a voiceover (presumably one of management) pledges to the workers to "do everything we can do keep you healthy, safe and protected" since "delivering ... to people now has never been more important." In the employee profile commercials, the viewer meets different workers in Amazon fulfillment centers, all of whom wear face masks and express pride in their jobs and gratitude towards a company that doubled its quarterly profits to $\$ 5.2$ billion during the pandemic. In "Meet Ricardo", a Latino sales associate uses American Sign Language to tell the viewer how Amazon supports him and his family by offering additional training and experience upon request. He adds that Amazon workers "are essential for the country to keep moving forward." In "Meet Janelle", a white area manager compares her fulfillment center to Willy Wonka's chocolate factory where "you have the golden ticket", an ironic analogy given the use of slave labor in Roald Dahl's classic tale. Apparently, the advertising campaign aimed to sublimate public support for striking workers into more online shopping. Despite the campaign, employees at Amazon as well as Instacart, Whole Foods, Target, FedEx and Walmart staged lunch-hour walkouts on International Workers' Day to remonstrate "their employers' record profits at the expense of workers' health and safety during the coronavirus pandemic" (Medina, 2020, par. 1).

Although the working conditions faced by supply-chain employees during the pandemic and customer service agents in Upload are not identical, a considerable overlap appears in the valorization of service work in the public imaginary. This is particularly evident in Upload's mockery of automation as a flawed historical development. The setting of the series is such that purportedly low-skilled work is increasingly replaced by artificial intelligence and automation, but often with mixed results. In various scenes robotic arms pose as grocery-store clerks but fail to understand customer requests; frenetic drones cram Amazon packages in Horizen's mail slot; and "taco drones" become soulless replacements for otherwise inimitable food trucks. Apparently, if racialized labor is both instrumental to the functioning of late capitalism and the comfort of white bourgeois culture it is also threatened by encroaching automation. Upload's depiction of this replacement, however, is rife with sarcasm, especially in scenes that illustrate the creepy ubiquity of Lakeview's nameless AI concierge. Of course, Nora rejects this automation, telling Nathan in Episode Two that "I'm not Siri, so look up your own news" and later, "I don't have to smile for you; I'm on break." In other words, Nora and her coworkers repeatedly insist on the merit and dignity of human labor against the pressures of an automated future, often by pushing back against workplace discipline and client demands.

Nora may indeed bend the rules to help clients and assert boundaries as an angel, but Aleesha is the more reliable rabblerouser at Horizen; her struggles are designed strictly to increase autonomy at work, redistribute power relations (if only momentarily) and negate client/customer entitlement. Aleesha encourages Nora to "fuck on Lucy's desk" and complains of Horizen's unreasonable frugality. She also gripes of how her supervisor is "up her ass", and quips about how underpaid she is as an angel, merely one job within her quiver of "gig work" that includes dog walker, restaurant manager, and hairstylist. Aleesha is particularly "meddlesome" in dealing with obstinate clients, most notably the lecherous Luke, Lakeview's resident gigolo. When Luke fails to help Aleesha (his angel) win a paid bonus, she slowly removes his avatar's fingers, insinuating that his penis might be next. As a warning to Luke, Aleesha boasts of her "fingers and dicks" collection, mutes his avatar and exclaims, "Now we play by my rules ... you goofy bitch." Most of Aleesha's antics resemble what James Scott might call the "prosaic ... ordinary means of class struggle", which include such banal forms of refusing work and its exploitative relations of production by loafing, theft, subterfuge, false compliance and sabotage (1989, p. 34).

For all of its strengths in emphasizing the importance of service work and assertiveness of angels, however, Upload is limited by the consistent ways in which it isolates deviance at the workplace. As Scott points out, this is not inherently problematic, as individual acts of insolence can have an aggregate effect on class struggle. That Daniels draws so heavily on Aleesha as the lone muckraking worker at Horizen, however, underscores how Upload conceptualizes labor politics, resistance and refusal of organizational discipline under late capitalism. The same collective struggle for affordable uploading found in the Luds is not extended to the workplace since the series is much more interested in the distribution of vital services than in the political economy of their provision, that is, the social relations of their production. Whereas Aleesha's refusals might correspond to Scott's description of "everyday resistance", they are 
rendered comical in Upload and might be dismissed as isolated mischief (which is perhaps the purpose), not unlike the pranks found in Daniels' earlier workplace comedies. They are depicted as individual aberrations rather than "widely practiced by members of an entire class", that is, defiant actions that might have "aggregate consequences all out of proportion to their banality when considered singly" (Scott, 1989, p. 34). As Scott argues, it is only "when such actions become sufficiently generalized to become a pattern of resistance [that] their relevance to class conflict is clear" (1989, p. 36). In Upload, Aleesha's minor acts of refusal fail to become "sufficiently generalized" across the workforce at Horizen, which points to larger problems with the series' depiction of service work.

While Nora's work as a customer service agent is obviously pivotal to client comfort and satisfaction in the afterlife as well as the development of the plot, Upload's approach to essential work is uneven and mixed. Most notably, the series fails to engage with its own "color-coded" divisions of labor, preferring instead to present a less prickly tableau of liberal multiculturalism. While Upload seems particularly skilled at satirizing workplace discipline in the post-industrial present and future, it is less inclined to challenge the racial hierarchies of labor it so carefully (if not intentionally) discloses to the audience. To be sure, we are never explicitly invited to question the disproportionate representation of people of color in service industries and low-wage labor nor are we encouraged to ponder the overrepresentation of brown and black passengers on public transit. Such an invitation might belie the series' liberal multicultural mood, which emphasizes racial equality and ostensibly recognizes "difference" but downplays economic disparities and racial divisions of labor even as it draws on them repeatedly. At Thanksgiving dinner, for example, Nathan visits his mother's modest home, which is decorated with not only a multiethnic cast of family members but also a 2024 political campaign poster for the duo of Oprah Winfrey and Kamala Harris. The message, of course, is that we are in the presence of exceptional white folks unrelated to the plutocrats responsible for socioeconomic disparity seen throughout the series. As if to confirm this "woke" whiteness, when Nathan first arrives at Lakeview and is told of its classic Americana design, he judgingly asks Nora, "Are there slaves here?"

Unfortunately, this is the extent to which the series approaches the racialized dimensions of socioeconomic inequality. Apparently, by 2033 racism is no longer relevant or worthy of public attention, despite the restriction of black and brown bodies to circumscribed scenes of the series, but predatory capitalism has shifted into overdrive. In fact, Nora's position at Horizen is explained as a result of economic circumstance rather than racial divisions of labor that typically consign people of color to low-skilled, low-paying jobs, as is presently the case in the service, hospitality, and retail industries in the US. That black, Latino, Asian-American and Eastern European migrants are concentrated in these positions of wage labor is neither openly acknowledged in the series nor is it disrupted, even as Horizen's white supervisor is depicted as caricature. As such, the racial division of labor becomes normalized in Upload in ways that not only conceal the limits of liberal multiculturalism but also prioritize a fantasy of limitless life potential for white characters, most notably Nathan.

\section{Conclusion}

In many ways, it is difficult to imagine how the workplace comedy might incorporate changing patterns and places of work in a pandemic era as well as how film and television production might feasibly take place at all with increased costs of health and safety measures, virus testing and physical distancing protocols. By midsummer of 2020, however, film and television production companies were gradually recording new material; Hallmark's "Countdown to Christmas" film marathon, for instance, was somehow able to create an inventory of 40 premieres for the winter season by filming throughout summer; Netflix released the documentary Totally Under Control (2020) and the feature-film obituary Death to 2020 (2020), both of which explicitly engaged with pandemic politics and the fallout of COVID-19; in December, Tom Cruise's tirade against crew members breaking physical-distancing protocol on the set of Mission Impossible 7 went viral, dramatizing the consequences of returning to production under COVID-19 conditions (five crew members quit the project as a result); in the same month Michael Mann released Songbird, his coronavirus disaster film that was met with abysmal reviews and widespread ridicule. Even some television sitcoms were able to resume filming. The sixth season of Superstore, for example, commenced in fall 2020 with an episode titled "Essential" that engaged with the fears and "new normal" of personal protective equipment and physical distancing at the level of plot development, perhaps a first for the genre in the COVID-19 era.

While it remains uncertain how popular film and television will reflect and react against the pandemic and its politics, we may find traces of a response in the workplace comedy, a genre allegedly on life support in 2016 but whose presence persists and shifts with the changing landscape of the workplace. As a workplace comedy written and produced before the widespread outbreak of COVID-19, however, Upload's social commentary is surprisingly relevant and touches on two central issues at the present historical moment: access to vital resources like health care and the importance of front-line, service and supply-chain workers, all of which became increasingly visible as "essential" to the basic functioning of daily life during the current health crisis. On the one hand, Upload is particularly sensitive towards disproportionate access to health care in the US, which certainly precedes the current health crisis but becomes 
glaringly obvious if not obscene during the COVID-19 catastrophe. As Gordon and Bruch explain, the widespread loss of health care coverage among Americans, for instance, is intimately related to sweeping job losses "at a time when early intervention and treatment are urgently needed" (2020, par. 3). This sense of urgency finds traction in Upload, particularly as it explicates the differences between residents of Lakeview and the Two Gig ghetto. Of course, access to an affordable afterlife in Upload is a coded critique of the neoliberal economics of health care and monetization of health in the US. On the other hand, Upload seems to take wage labor more seriously than other workplace comedies and earlier Daniels projects like The Office and Parks and Recreation. In Upload "bullshit jobs" have been replaced by essential service work performed by "angels" and avatars in virtual worlds of the afterlife and are central to the development of the series' various plotlines.

Whereas Upload may be acutely sensitive to the struggles for affordable health care that overlap with the pandemic era, it seems myopic in its understanding of structural racism that also informed the morbidity rates of COVID-19, which disproportionately effects black and Latina/o communities. To this end, the series may offer an incisive indictment of health care and its privatization but falls well short of understanding how and to whom it is distributed. Upload's cynical overview of health care might inform our understanding of the death toll of COVID-19 in the US, but not how "structural racism shapes the distribution of social determinants of health and social risk factors" (Leonard \& Walker, 2020, par. 4). In addition, its disruption to the exploitative social relations of production brought to light during the pandemic is mostly individualized and relegated to the outbursts and mischief of a secondary character: Nora's co-worker, Aleesha. As such, we are not explicitly encouraged to take labor struggles nearly as seriously as the collective struggle over health care issues and access to critical resources and health care. To this end, Upload is mostly concerned with the politics of consumption under late capitalism rather than its production, which renders the social commentary of the series somewhat lopsided.

\section{References}

Al-Gharbi, M. (2020). Disposable People. The Baffler, 1 April. Retrieved 10 April 2020 from https://thebaffler.com/latest/disposable-people-algharbi

Berlatsky, N. (2020). "Upload" on Amazon tackles capitalism and the afterlife—with a surprisingly hopeful message. NBC News, 2 May. Retrieved $19 \quad$ May 2020 from https://www.nbcnews.com/think/opinion/upload-amazon-tackles-capitalism-afterlife-surprisingly-hopeful-message -ncna1198196

Brabazon, T. (2005). "What have you ever done on the telly?": The Office, (post) reality television and (post) work. International Journal of Cultural Studies, 8(1), 101-117. https://doi.org/10.1177/1367877905050166

Bragman, W. (2020). Coronavirus has made a fool out of every single critic of Medicare for All. Jacobin, 13 August. Retrieved 10 September 2020 from

https://jacobinmag.com/2020/08/coronavirus-medicare-for-all-single-payer?fbclid=IwAR0hPgZ8fVYRsBGoCjwa

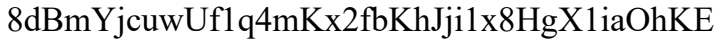

Bramesco, C. (2020). Upload review: Amazon's afterlife comedy is the less good place. The Guardian, 30 April. Retrieved 8 May 2020 from https://www.theguardian.com/tv-and-radio/2020/apr/30/upload-review-amazon-afterlife-comedy-less-good-place

Buchanan, K. (2020). The future that Hollywood feared is happening now. The New York Times, 13 April. Retrieved 24 May 2020 from https://www.nytimes.com/2020/04/15/movies/hollywood-new-films-coronavirus.html

Burgess, J., \& Connell, J. (eds). (2006). Developments in the Call Centre Industry: Analysis, Changes, Challenges. New York, NY, and London, UK: Routledge. https://doi.org/10.4324/9780203003008

Crary, J. (2013). 24/7: Late capitalism and the ends of sleep. London, UK, and New York, NY: Verso.

D'Addario, D. (2020). Greg Daniels' Upload: TV review. Variety, 24 April. Retrieved 1 May 2020 from https://variety.com/2020/tv/reviews/upload-amazon-review-greg-daniels-1234588470/

Dow, B. (1996). Prime-time feminism: Television, media culture and the women's movement since 1970. Philadelphia, PA: University of Pennsylvania Press.

Dubrofsky, R. (2002). Ally McBeal as postfeminist icon: The aestheticizing and fetishizing of the independent working woman. The Communication Review, 5(4), 264-284. https://doi.org/10.1080/10714420214690

Fairclough, N. (1995). Media discourse. London, UK: Edward Arnold.

Fairclough, N. (2003). Analyzing discourse. New York, NY, and London, UK: Routledge. https://doi.org/10.4324/9780203697078 
Francisco, E. (2020). Amazon's Upload is where The Good Place and Snowpiercer collide. Inverse, 22 April. Retrieved 1 May 2020 from https://www.inverse.com/entertainment/upload-review-amazon

Gilbert, S. (2020). Upload satirizes a capitalist heaven. The Atlantic, 7 May. Retrieved 24 May 2020 from https://www.theatlantic.com/culture/archive/2020/05/upload-black-mirror-hell-digital-heaven/611293/

Gordon, C., \& Bruch, S. (2020). COVID-19 is exposing the United States’ ragged, shameful safety net. Jacobin, 21 April. Retrieved 10 May 2020 from https://www.jacobinmag.com/2020/04/covid-19-social-safety-net-united-states?fbclid=IwAR0kQWytS5BFQHuSR QJPrKw_qrCf6J3BjuApNGNQBA293090az3DXbYZJkM

Graeber, D. (2018). Bullshit jobs: A theory. New York, NY: Simon and Schuster.

Greene, S. (2020). "Upload" review: a forced futuristic rom-com that's more artificial than reality. Indie Wire, 1 May. Retrieved 10 May 2020 from

https://www.indiewire.com/2020/05/upload-review-amazon-prime-video-comedy-1202227640/

Haskaj, F. (2018). From biopower to necroeconomies: Neoliberalism, biopower and death economies. Philosophy and Social Criticism, 44(1), 1148-1168. https://doi.org/10.1177/0191453718772596

Hess, A. (2020). The pandemic ad salutes you. The New York Times, 22 May. Retrieved 1 June 2020 from https://www.nytimes.com/2020/05/22/arts/pandemic-ads-salute-you.html

Hunt, K. (2016). The slow, painful death of the workplace sitcom. GQ, 25 October. Retrieved 2 April 2020 from https://www.gq.com/story/rip-workplace-sitcom

Kellner, D. (1995). Media culture. London, UK, and New York, NY: Routledge.

Leonard, E., \& Walker, R. (2020). Structural racism, social risk factors, and COVID 19: A dangerous convergence for black Americans. New England Journal of Medicine, 17 September. Retrieved from https://www.nejm.org/doi/full/10.1056/NEJMp2023616

Mbembe, A. (2003). Necropolitics. Public Culture, 15(1), 11-40. https://doi.org/10.1215/08992363-15-1-11

Medina, D. (2020). As Amazon, Walmart and others profit amid coronavirus crisis, their essential workers plan unprecedented strike. The Intercept, 28 April. Retrieved 1 May 2020 from https://theintercept.com/2020/04/28/coronavirus-may-1-strike-sickout-amazon-target-whole-foods/

Ouellette, L. (2002). Victims no more: Postfeminism, television, and Ally McBeal. The Communication Review, 5(4), 315-335. https://doi.org/10.1080/10714420214689

Scott, J. (1989). Everyday resistance. Copenhagen Papers, 4, 33-62. https://doi.org/10.22439/cjas.v4i1.1765

Sepinwall, A. (2020a). Upload review: A familiar trip to TV heaven. Rolling Stone, 28 April. Retrieved 1 May 2020 from https://www.rollingstone.com/tv/tv-reviews/upload-review-amazon-prime-series989474/

Sepinwall, A. (2020b). Has Covid leveled peak TV? Rolling Stone, 15 October. Retrieved 10 December 2020 from https://www.rollingstone.com/tv/tv-features/covid-precaution-protocol-budget-netflix-cancel-peak-tv-1075454/

Tyner, J. (2019). Dead labor: Toward a political economy of premature death. Minneapolis, MN: University of Minnesota Press. https://doi.org/10.5749/j.ctvckq9nc

VanArendonk, K. (2020). Upload is bleak as hell. Vulture, 7 May. Retrieved 20 May 2020 from https://www.vulture.com/2020/05/upload-amazon-review.html

\section{Copyrights}

Copyright for this article is retained by the author(s), with first publication rights granted to the journal.

This is an open-access article distributed under the terms and conditions of the Creative Commons Attribution license which permits unrestricted use, distribution, and reproduction in any medium, provided the original work is properly cited. 